\title{
Effect of Enhanced Air Temperature (extreme heat), and Load of Non-Linear Against the Use of Electric Power
}

\author{
I Ketut Wijaya
}

\begin{abstract}
Abstrac- Usage Electric power is very easy to do, because the infrastructure for connecting already available and widely sold. Consumption electric power is not accompanied by the ability to recognize electric power.

The average increase of electricity power in Bali in extreme weather reaches $10 \%$ in years 2014 , so that Bali suffered power shortages and PLN as the manager of electric power to perform scheduling on of electric power usage. Scheduling is done because many people use electric power as the load of fan and Air Conditioner exceeding the previous time. Load of fan, air conditioning, and computers including non-linear loads which can add heat on the conductor of electricity. Non-linear load and hot weather can lead to heat on conductor so insulation damaged and cause electrical short circuit. Data of electric power obtained through questionnaires, surveys, measurement and retrieve data from various parties.

Fires that occurred in 2014, namely 109 events, 44 is event caused by an electric short circuit (approximately 40\%). Decrease power factors can cause losses of electricity and hot. Heat can cause and adds heat on the conductor electric.

The analysis showed understanding electric power of the average is 27,700 with value between 20 to 40 . So an understanding of the electrical power away from the understand so that many errors because of the act own. Installation tool ELCB very necessary but very necessary provide counseling of electricity to the community.
\end{abstract}

Key Words- Extreme weather (Hot), Electrical Power, User of Electric Power

\section{INTRODUCTION}

Electric power is currently very expensive, because electric power is difficult to be developed and the development of electric power can not be done due to various problems and needs. In various issues of human life, power still holds a very important role as a means to support the success of the work done. The role of electric power can not be separated from the increasing the number of population, the activities carried out for life, and comfort in life.

Of electric power in relation to human life is very important (to turn on the fan and air conditioner), because the Indonesian state is a tropical country. Nonlinear load (fan, air conditioners, and computers) can cause electric losses and heat on to the conductor of electricity. The hot weather conditions and non-linear loads may cause a fire due to a short circuit on both channels. The tropical weather in Indonesia is very influential on the use of electric power. Utilization of electric power in hot climatic conditions at a temperature $31-32^{\circ} \mathrm{C}$, the use of electric power reached $3.1 \%$ Megawatts in 2013 . In 2014 the use of electricity in Bali jumped sharply so that the utilization of electricity is considered extreme and reaches $10 \%$ from $712.5 \mathrm{MW}$ up to $780.9 \mathrm{MW}$ [10]. Supply of electric power in the State Electric Company (PLN) only reached 880 MW this year, namely 2014. Supply of electric power can not be utilized in full, due to constraints on the distribution of the existing distribution tower at Celukan Bawang. Bali has multiple sources of power generation Diesel 18 pieces and 7 pieces of gas power plants.

Electricity is very expensive and PLN Bali has not been able to add electric power to the benefit of society. Looking at it from this condition is necessary to study in order to know why electricity is used excessively.

\subsection{Problem Formulation}

From the problems above can be prepared formulation of the problem as follows:

1. Why is the excessive use of electricity in?

2. How is the link between the fire with non-linear load?

3. How does the ability of people to use electricity?

\subsection{Benefits Research}

The benefits of this research are:

1. Useful as additional reference material for researchers who want to investigate with regard to electricity.

2. As an additional input for PLN in preparedness with regard to natural summer Bali.

3. Adding additional knowledge related to electricity in Electrical Engineering University of Udayana Bali.

\section{Matreials AND Methods}

The material in this study are power generation, distribution channels managed PLN and society which use the electricity power.

The method used is a method surve, interviews, internet and reading books that all will be aggregated and processed to be a result of research. The data which shaped figure will be analyzed with the help of the program to get the results that will be used to replenish and strengthen the research report.

\section{WAY DO RESEARCH}

Research done by:

a. Writing to the theory

b. Searching data PLN and BPBDs Denpasar.

c. Doing surve and questionnaires for consumption electric power to public.

d. Conducted an analysis of the data obtained. 


\subsection{Results}

\section{RESULTS AND DISCUSSION}

5.1.1 The use of electricity power in Bali.

The use of electricity power in Bali fluctuate appropriate to weather conditions.

Table 1. Usage Peak Load of Electrical Power Based on Data PLN

\begin{tabular}{clccc}
\hline No. & Month & $\begin{array}{c}\text { Electricity } \\
\text { Consumption }\end{array}$ & Difference & $\begin{array}{c}\text { Procentage } \\
(\%)\end{array}$ \\
\hline 1 & January & 646.73 & & 1 \\
2 & February & 653.575 & 6.845 & 2 \\
3 & March & 661.447 & 14.717 & 10 \\
4 & April & 692.673 & 45.943 & 10 \\
5 & May & 702.191 & 55.461 & 7 \\
6 & June & 693.493 & 46.763 & 0 \\
7 & Julyi & 649.1 & 2.37 & 3 \\
8 & August & 667.287 & 20.557 & 6 \\
9 & September & 684.455 & 37.725 & 12 \\
10 & October & 726.274 & 79.544 & 16 \\
11 & November & 750.123 & 103.393 & 8 \\
12 & December & 697.783 & 51.053 & 6.8 \\
\hline
\end{tabular}

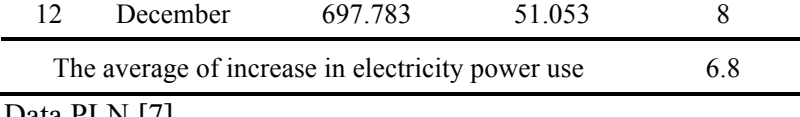

In 2014 the data obtained from the PLN for one year showed that electricity in Bali already at alarming point that is at the point of $750.123 \mathrm{MW}$ of the $880 \mathrm{MW}$ generated PLN, so must the addition of electric power by adding a new power plant.

Table 2. Electricity Consumption in One House with the Load 1300

\begin{tabular}{clc}
\multicolumn{2}{c}{ VA in Denpasar, Year 2014 } \\
\hline No & Month in Year 2014 & $\begin{array}{c}\text { Electricity Consumption } \\
(\text { Rp. })\end{array}$ \\
\hline 1 & January & $218,166.00$ \\
2 & February & $233,826.00$ \\
3 & March & $238,502.52$ \\
4 & April & $250,193.82$ \\
5 & May & $288,645.85^{*}$ \\
6 & June & $255,197.70$ \\
7 & Julyi & $245,657.60$ \\
8 & August & $252,202.58$ \\
9 & September & $264,812.70$ \\
10 & October & $282,466.88^{*}$ \\
11 & November & $307,182.74^{*}$ \\
12 & December & $285,997.72^{*}$ \\
\hline
\end{tabular}

Results Research [12]

Consumption of electric power in one the household on the load $1300 \mathrm{VA}$ (Table 2.), seen there are an increase in in conjunction with an increase in hot conditions which occur in Bali namely in November 2014 .

Table 3. Data The Tools for Leisure Yang Used Household in Denpasar

\begin{tabular}{|c|c|c|c|c|c|c|}
\hline \multirow[b]{3}{*}{$\begin{array}{c}\text { No } \\
\text {. }\end{array}$} & \multicolumn{6}{|c|}{ Load 1300 VA in Years 2014 on Extreme Conditions } \\
\hline & \multicolumn{3}{|c|}{ Fan } & \multicolumn{3}{|c|}{ Air condisioner } \\
\hline & $\begin{array}{c}\text { Muc } \\
\mathrm{h}\end{array}$ & $\begin{array}{l}\text { Usage } \\
\text { Before } \\
\text { occurren } \\
\text { ce of } \\
\text { Climate } \\
\text { Change } \\
\text { (hours) }\end{array}$ & $\begin{array}{l}\text { Usage } \\
\text { After the } \\
\text { occurren } \\
\text { ce of } \\
\text { Climate } \\
\text { Change } \\
\text { (hours) }\end{array}$ & $\begin{array}{c}\text { Muc } \\
\mathrm{h}\end{array}$ & $\begin{array}{l}\text { Usage } \\
\text { Before } \\
\text { occurren } \\
\text { ce of } \\
\text { Climate } \\
\text { Change } \\
\text { (hours) }\end{array}$ & $\begin{array}{l}\text { Usage } \\
\text { After the } \\
\text { occurren } \\
\text { ce of } \\
\text { Climate } \\
\text { Change } \\
\text { (hours) } \\
\text { much }\end{array}$ \\
\hline 1 & 2 & 8 & 12 & 1 & 9 & 12 \\
\hline 2 & 1 & 8 & 13 & & & \\
\hline 3 & 3 & 9 & 13 & 1 & 8 & 13 \\
\hline 4 & 2 & 8 & 10 & & & \\
\hline 5 & 2 & 8 & 13 & 1 & 8 & 10 \\
\hline 6 & 2 & 8 & 13 & & & \\
\hline
\end{tabular}

Tools that make human life more comfortable while in the house is the fan and air conditioning (see Table 3 ). The existence of this tool is required at rest the night to make the room more airy and comfortable.

\begin{tabular}{|c|c|c|c|c|}
\hline \multirow[b]{2}{*}{ No } & \multirow[b]{2}{*}{ Month } & \multicolumn{3}{|c|}{ Year 2013} \\
\hline & & $\begin{array}{l}\text { number of } \\
\text { fires }\end{array}$ & location & $\begin{array}{l}\text { because } \\
\text { Electricity }\end{array}$ \\
\hline 1 & January & 8 & Denpasar & 7 \\
\hline 2 & February & 7 & Denpasar & 3 \\
\hline 3 & March & 0 & Denpasar & 1 \\
\hline 4 & April & 7 & Denpasar & 5 \\
\hline 5 & May & 8 & Denpasar & 5 \\
\hline 6 & June & 5 & Denpasar & 3 \\
\hline 7 & Julyi & 5 & Denpasar & 4 \\
\hline 8 & August & 4 & Denpasar & 3 \\
\hline 9 & September & 13 & Denpasar & 3 \\
\hline 10 & October & 15 & Denpasar & 9 \\
\hline 11 & November & 20 & Denpasar & 5 \\
\hline 12 & December & 21 & Denpasar & 7 \\
\hline & & 113 & & 55 \\
\hline
\end{tabular}

Data from [4]

The amount of data a fire that occurred in 2013 in Denpasar, which is caused by electric power is still quite high every month. 
Table 5. Fires Occurs Due to electricity in Denpasar in 2014

\begin{tabular}{clclc}
\hline \multirow{2}{*}{ No } & Month & \multicolumn{3}{c}{ Year 2014 } \\
\cline { 3 - 5 } & & $\begin{array}{c}\text { number } \\
\text { of fires }\end{array}$ & location & $\begin{array}{l}\text { because } \\
\text { Electricity }\end{array}$ \\
\hline 1 & January & 3 & Denpasar & 2 \\
2 & February & 7 & Denpasar & 6 \\
3 & March & 0 & Denpasar & 0 \\
4 & April & 7 & Denpasar & 5 \\
5 & May & 5 & Denpasar & 5 \\
6 & June & 5 & Denpasar & 5 \\
7 & Julyi & 9 & Denpasar & 1 \\
8 & August & 8 & Denpasar & 2 \\
9 & September & 5 & Denpasar & 3 \\
10 & October & 28 & Denpasar & 5 \\
11 & November & 6 & Denpasar & 6 \\
12 & December & 26 & Denpasar & 4 \\
\hline & Total & 109 & & 44 \\
\hline Data from [4] & & &
\end{tabular}

In Table 5. Reduction the number of fires that occurred in 2013 and 2014 , about $20 \%$, but the fires are still in alarming levels.

Table 6. Effect Load of Electronic Against Heat (Flow)

\begin{tabular}{lrr}
\hline \multirow{2}{*}{$\begin{array}{l}\text { Variable of } \\
\text { Measuring }\end{array}$} & \multicolumn{2}{c}{ Load of Computer } \\
\cline { 2 - 3 } Power Factor & 0.72 & without Arde \\
Current (Amp.) & 2.13 & 0.57 \\
Voltage (Volt)) & 224.6 & 2.35 \\
Watt & 265 & 224.4 \\
Var & 395 & 330 \\
\hline Results Analysis Research [12] & & 441 \\
\end{tabular}

Electronic load (non-linear load) can cause decline of power factor and causes a current to be big.

Table 7. Analysis User of Electric

\begin{tabular}{lccc}
\multicolumn{1}{c}{ Data } & $\mathrm{N}$ & Mean & Std. Deviation \\
\hline $\begin{array}{l}\text { User of Electric } \\
\text { Power }\end{array}$ & 10 & 27.700 & 7.439 \\
\hline Results Analysis Research [12]
\end{tabular}

Results of analysis on questionnaire showed that users electrical household provide the results are not satisfactory to the understanding of the tools used in the installation to electricity until the to use electric power.

\subsection{Discussion}

\subsubsection{The use of excessive electric power}

a. Electrical conditions in Bali

The conditions of electric power currently in critical condition, because the peak load almost reach total of the electric power generated. This condition triggering the rolling blackouts are carried out by PLN in order to avoid damage to the distribution channel. The increase in the use of electricity occurs between $1 \%$ to $16 \%$ with an average of $6.8 \%$ (see Table 1). Increased use of electric power is highest in November 2014.

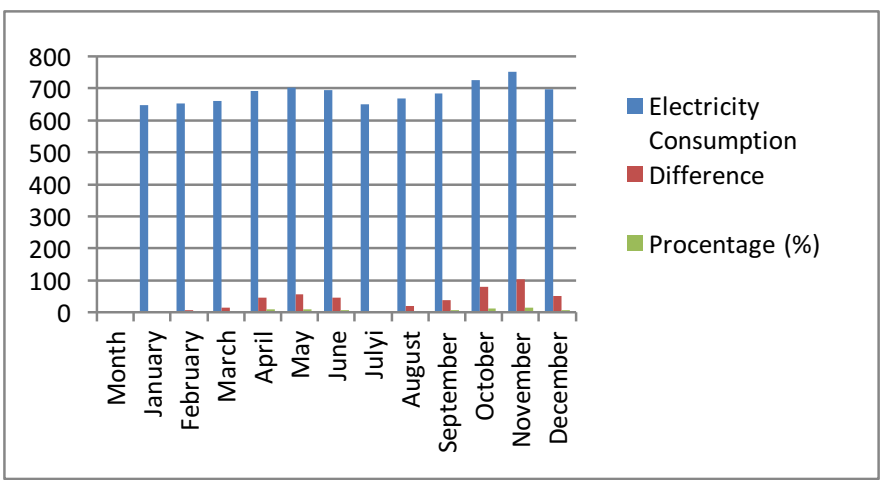

Graph 1. Consumption, Difference and Percentage of Use of Electric Power

\section{b. Using the appliance of excessive comfort}

Increased use of electric power caused by the use of equipment in the use of excessive electric power (fan and water condisioner (Tabel 3.)). Use of this conditioning tool can provide comfort in the body through the coolness issued by these tools. Electrical tools used excessively can lead to paying more electricity (see Tabel 2.).

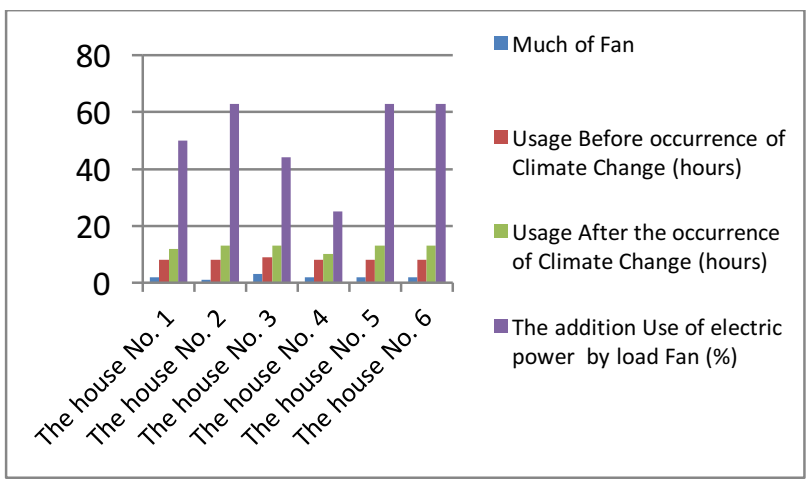

Graph 2. The Data Using of Fan

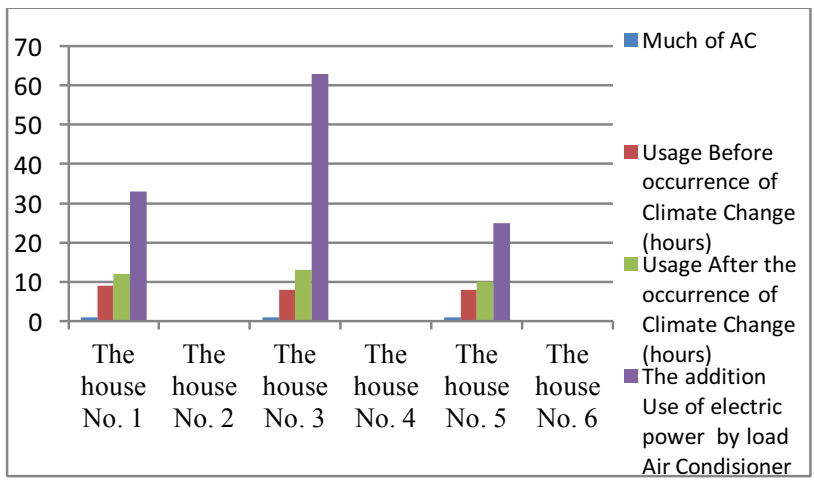

Graph 3. The Data Using of Air Conditioner 


\section{c. Conditions extreme in Bali (excessive heat)}

In 2014 occurred condition extreme in Bali, the temperature reaches $31 \mathrm{oC}$ which caused electricity consumption increased (see Table 2). The enhancement of the use of electric power as a result of the use of the convenience tool on extreme conditions is $51 \%$ for the use of the fan and $40 \%$ for use of AC. At such extreme conditions this very need to be aware of impending fires caused by electricity. In Table 4 and Table 5 , fires due to electricity are still quite high result of extreme temperature conditions in Bali. Hot temperatures provide heat on the cable so that the cable get additional heat from the outside and due to excessive load which causes the cable insulation peeled off [2], [5], [8]. If two cables that exfoliate led to short-circuit that caused the fire [9].

d. Electric power used

Electric power used is still at the stage for convenience, because tropical conditions as the cause in Bali. The use of electricity power for businesses are still not widely used, moreover condition the economy is still recovering from the downturn. In Bali the electric power used on the manufacture of canang by the Balinese people to be sold in the morning. Electric power (in Table 2) it appears that in the its use of increasingly expensive to paid per month, because in the manufacture of canang can be ascertained using a fan. This means that weather conditions are also very influential on the use of electric power. At the extreme weather namely in April, May, June, October, November and December 2014 electric power consumption is quite high [4].

e. Fires caused by electricity

The use of electric power without coupled with knowledge that has not been either the cause of the fire (Table 4 and Table 5). In Table 4 (in 2013) and Table 5 (2014) shows that the fires which caused by electric quite big. In 2013 there is a fire as many as 113 times and fires caused by electricity alone 55 times. Fires caused by electricity as much as $50 \%$ of the total fires which happened. While the fires in 2014 occurred as much as $40 \%$ of the total fires. So accidents due to electrical short circuit can be said is still quite high.

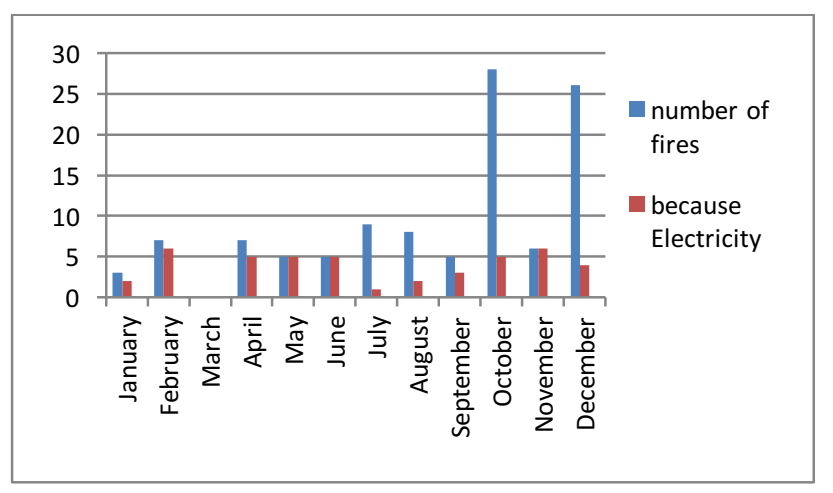

Graph 4. Fires Due to Electrical

Many of the electric power users do not understand the use of electricity with nicely, such as the use of stickers $\mathrm{T}$ piled a lot, or installed by those who have not have the certificate expert of electricians. Installation of electric power must meet the criteria set by PLN [9]. The fact say that still many electrical instalas not installed by an expert and do not yet understand the true with the regulations issued by PLN.

The formula of prisoners RT2 $=\mathrm{Rt} 1+\alpha(\mathrm{t} 2-\mathrm{t} 1)$ [2]. In the formula looks if the wire has impedance which given load (electric current) then there is the heat flowing on the wire. Additional heat is obtained from the hot weather so that impedance of wire will increase. With the increase in temperature and impedance wire size will damage the wire insulation. Damaged insulation will cause electrical short circuit [2], [5].

To overcome the problem of fires must use the currentlimiting MCB which the good one, in addition to the installation and connection as well as isolation must be true, because the tool is able to protect the building from fire. Use ELCB (Earth Leakage Circuit Breaker) make more secure and comfortable. ELCB very sensitive tool with the capabilities of the 0.03 Ampere to keep in case of connection to the earthing [13]. Two of these tools are to be installed in order to avoid problems due to electricity so that, life becomes comfortable. Comfort constitute case that the principal and is a necessity in regard to achieving performance [6].

\subsubsection{Heat due to non-linear load}

Electronic load (non-linear load) resulted in a wave of voltage or current source of electric power distorted, so it will degrade the quality of electric power resulting in excessive heating in the conductor, a decrease in the power factor, cause resonance, and harmonics [12], [13]. Harmonics are caused by non-linear load, so that load non-linear needs to be reduced so that the bad effects do not occur and does not interfere with the performance of other equipment connected to the same source.

Harmonics also cause heat to the on transformer so that can lowering efficiency the transformer and consequently transformer can get burned [12].

The greater the harmonics, the greater the power loss and voltage drop across the channel, as well as the influence of these can decreased power factor.

Voltage drop which experienced of electric power enable user of electric power not receive full voltage of 220 Volt [3].

In Table 6 shows that the influence of power factors greatly affect the heat generated on the conductor of electric power system. Table 6. Also shown that the nonlinear load can provide heat or losses in the electric power system. Losses of the electric power system due to non-linear loads can be overcome by installing capacitors [1]. 


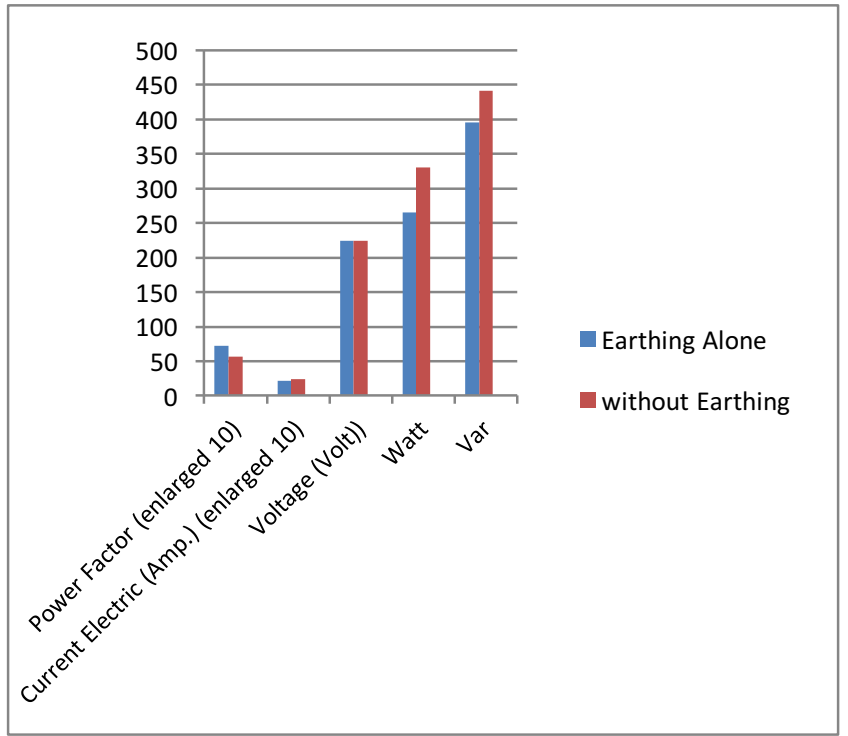

Graph 5. Effect of Non Linear Load

\subsubsection{Knowledge electricity user}

Seeing the results of the research that was done with questionnaire is that there are still many electricity users not understand with condition electricity in his home. Research results obtained with the average of 27,700 between the value assigned 20 to 40 said that user electric power still far away from understand will the use of electric power correctly(see Table 7). For that must done the introduction of electricity power by giving lectures on electric power by the agency authorized [6].

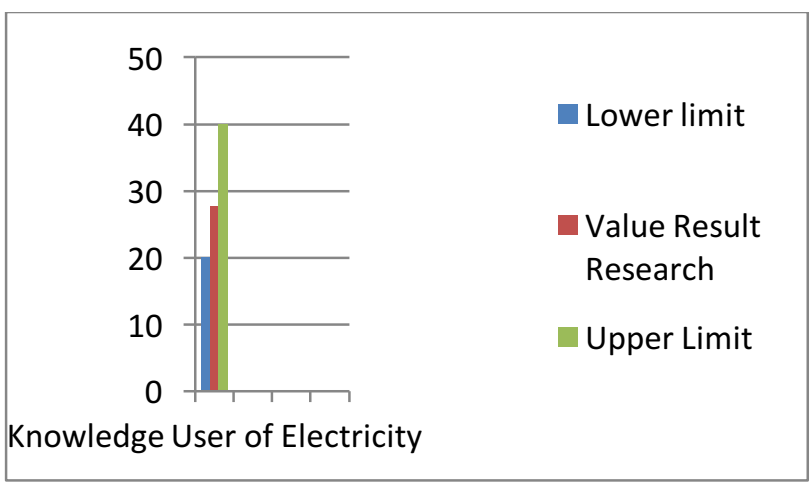

Graph 6. Knowledge User of Electricity

\section{CONCLUSION}

From the foregoing it is necessary made the conclusions:

1. Communities in Bali is already accustomed to use electricity. Communities in Denpasar, Bali using of electricity power more much to as lighting, cooking the rice, fans, and air conditioning. Hot weather in 2014 a lot of causing electrical fires in Denpasar. More fires are caused by human error, because the electricity has not been well understood.

2. Very need to be given an explanation on an ongoing basis to remind that if, either intentionally or unintentionally the violation of rules PLN, the result would be a fires. Advised to use the means that have a standard electrical installation and install additional tools MCB and ELCB which good to avoid fires and earthing through the human body.

3. It takes an active role relevant agencies to provide continuous warning to the public to reduce the impact less on understanding about electricity from mounting up to use electric power.

\section{ACKNOWLEDGMENTS}

I am grateful to Prof. I Made Sutajaya and Prof. I Dewa Putu Sutjana above guidance and enter the given. Hopefully we can cooperate well.

\section{REFERENCES}

[1] Adrianus, 2009. Minimizing Loss -Rugi On System Medium Voltage Distribution With Capacitor Installation. Accessed August 8, 2015. Assignment End.

[2] Admin. 2013. Why Shorted Often Causes Fires. Accessed Date June 13, 2015.

[3] Antonov dan Natalinus, 2013. Antonov and Natalinus, 2013. Effects of Changes in Voltage Source on the Characteristics of Power Factor On Energy Saving Lamps. Jurnal Teknik Elektro Volume 2, No. Institut Teknologi Padang.

[4] BPBD, 2015. Data from the Regional Disaster Management Agency Denpasar in 2013 through 2014. Accessed 11.30 Date June 15, 2015.

[5] Electro Indonesia, 1999. How occurrence the fires. Accessed Date June 12, 2015.

[6] Manuaba, A. 2005. Total Ergonomics Enhancing Productivity, Product Quality and Customer Satisfaction. National Seminar 2nd on Quality Improvement in Manufacturing Systems and Services. Yogyakarta, 30 April.

[7] PLN, 2014. Daily Expenses Sub System Bali. Taken On May 12, 2015.

[8] PLN, 2011. Use of Electrical which Wrong causing fire . PT PLN (Persero). Distribution Jakarta and Tangerang. Accessed Date June 17, 2015.

[9] PUIL, 2000. General Regulation of Electrical Installations (PLN). Company General of Electric country (PLN).

[10] Redika, 2014. Electricity consumption in Bali Skyrocketed. Bali Post Umanis Thursday, 13 November 2014. Source Public Relations State Electricity Distribution Company Bali.

[11] Supri Hardin Dan Yamani, 2013. Reduction Harmonics and Correction Power Factor the applications of burden of household . journal Litek.

[12] Wijaya, 2015. Research Result. This study was conducted from January to June 2015.

[13] Wikipedia, 2014. Tips to Prevent of Flow Short of Electrical. Accessed Date June 16, 2015. 
[Type text] 